\title{
Structural and Optical properties of $\mathrm{P}_{2} \mathrm{O}_{5}-\mathrm{ZnO}-\mathrm{Na}_{2} \mathrm{O}-\mathrm{Li}_{2} \mathrm{O}$ glasses
}

\author{
Naglaa F. Osman ${ }^{\text {a }}$, Mohamed M. Elokr ${ }^{\text {b }}$, Lalia I. Soliman ${ }^{\text {c }}$, Hamdia A. Zayed ${ }^{\text {d }}$ \\ ${ }^{a}$ Physics Department, Modern Academy for Engineering and Technology in Maadi, Cairo, Egypt \\ ${ }^{\mathrm{b}}$ Physics Department, Faculty of Science, Al-Azhar University, Cairo, Egypt \\ ${ }^{\mathrm{c}}$ National Research Center, Dokki, Cairo, Egypt \\ ${ }^{\mathrm{d}}$ Physics Department, Faculty of Women, Ain Shams University, Cairo, Egypt
}

\begin{abstract}
The transparent glasses of composition $40 \mathrm{P}_{2} \mathrm{O}_{5}-20 \mathrm{ZnO}-(40-\mathrm{x}) \mathrm{Na}_{2} \mathrm{O}-\mathrm{xLi}_{2} \mathrm{O}$ have been prepared using conventional melt quenching technique (where $0 \leq \mathrm{x} \leq 25 \mathrm{Li}_{2} \mathrm{O}$ mol. \%). The prepared glass samples were characterized by $\mathrm{x}$-ray diffraction (XRD), differential thermal analysis (DTA), UV-VIS optical absorption and Fourier transform infrared spectroscopy (FTIR). The differential thermal analysis (DTA) studies showed that the glass transition temperature $\left(\mathrm{T}_{\mathrm{g}}\right)$ decreases from $558 \mathrm{~K}$ to $546.7 \mathrm{~K}$ as the content of $\mathrm{Li}_{2} \mathrm{O}$ increases to $25 \mathrm{~mol} . \% \mathrm{Li}_{2} \mathrm{O}$. The density and oxygen packing density measurements are found to be increase while the molar volume decreases with increasing of $\mathrm{Li}_{2} \mathrm{O}$ content. The FTIR studies revealed that these glasses consist of $\mathrm{Q}^{3}, \mathrm{Q}^{2}, \mathrm{Q}^{1}$ and $\mathrm{Q}^{0}$ structural units. Absorbance of investigated glasses was measured and used to estimate their optical absorption coefficient and optical energy gap. The optical studies revealed that the indirect optical band gap $\left(\mathrm{E}_{\mathrm{g}}\right)$ decreases from 3.33-2.64 eV and Urbach energy increases from $0.46-2.4 \mathrm{eV}$ with increase of $\mathrm{Li}_{2} \mathrm{O}$ content from zero to $25 \mathrm{~mol}$. $\% \mathrm{Li}_{2} \mathrm{O}$.
\end{abstract}

Key words: phosphate glasses, structure properties, Optical properties.

\section{Introduction}

The synthesis and physical properties of phosphate glasses have attracted much attention because of their potential application in technology. Phosphate glasses possess a series of interesting and unique physical properties better than other glasses such as hardness, transparency at room temperature, sufficient strength, low glass transition temperature, excellent corrosion resistance, high electrical conductivity, low melting and softening temperature and high thermal expansion [Yahia H. Elbashar et al. (2016), R. K. Brow et al (1995), Samir Y. Marzouk et al (2009), A. Bhide et al (2007), R. K. Brow (2000), I. Abrahams et al (2000)]. Among oxide glasses, sodium and lithium phosphate glasses/glass-ceramics are used as solid electrolytes for battery applications [Paramjyot Komar Jha et al (2015), A. Yamano et al (2014)]. Phosphate glasses have been considered as a promising group of glasses for optical amplifiers, fibers, etc. [A.V. Chandrasekhar et al (2003), Nehal Aboulfotoh et al (2014)] and also play various important roles in laser systems.

*Corresponding Author : hamdia44@yahoo.com

For laser application glasses used as transmitting optical components, as modulators, for photonic switching and magneto-optic materials [D. D. Ramteke et al (2017)]. By varying the glass composition, glasses with specific properties can be achieved. Several studies have been shown that a chemical durability of phosphate based glasses can be improved by the addition of various oxides[S. T. Reis et al (1998), D. E. Day et al (2001)]. It is found that, the chemical durability of 
phosphate glasses improved by the addition of $\mathrm{ZnO}$ because $\mathrm{Zn}^{2+}$ ion acts as an ionic cross linker between different phosphate anions, inhibiting hydration reaction. $\mathrm{ZnO}$ acts as a glass modifier, where $\mathrm{Zn}^{2+}$ occupies interstitial sites in glass network [D. Carta et al (2009)]. With the addition of $\mathrm{ZnO}$ to phosphate glasses, the $\mathrm{P}-\mathrm{O}-\mathrm{P}$ bonds are replaces by more chemically durable $\mathrm{P}-\mathrm{O}-\mathrm{Zn}$ bond [R. K. Brow et al (1995)]. The addition of $\mathrm{ZnO}$ to phosphate glasses is interesting because the $\mathrm{ZnO}-\mathrm{P}_{2} \mathrm{O}_{5}$ systems show unusual change in correlation between the structural and optical properties (e.g.: mass density, refractive index and ultraviolet absorption edge) at the metaphosphate composition [P. M. V. Teja et al (2012)].

In literature we find that the optical property of $\mathrm{P}_{2} \mathrm{O}_{5}-\mathrm{ZnO}-\mathrm{Na}_{2} \mathrm{O}-\mathrm{Li}_{2} \mathrm{O}$ glass system have not been studied extensively for this reason, the present work gives the preparation of $40 \mathrm{P}_{2} \mathrm{O}_{5}-20 \mathrm{ZnO}-(40-\mathrm{x}) \mathrm{Na}_{2} \mathrm{O}-\mathrm{xLi}_{2} \mathrm{O}$ glasses containing varying concentration of $\mathrm{Li}_{2} \mathrm{O}$ reaching to $25 \mathrm{~mol} . \%$ and the investigation of their structure and optical properties.

\section{Experimental}

\subsection{Preparation of the glasses}

The investigated glasses $40 \mathrm{P}_{2} \mathrm{O}_{5}-20 \mathrm{ZnO}-(40-\mathrm{x}) \mathrm{Na}_{2} \mathrm{O}-\mathrm{xLi} 2 \mathrm{O}(0 \leq \mathrm{x} \leq 25)$ were prepared by the conventional melt quenching technique using high purity analytical grade chemicals $\left(\mathrm{NH}_{4}\right)_{2} \mathrm{HPO}_{4}, \mathrm{ZnO}, \mathrm{Na}_{2} \mathrm{CO}_{3}$ and $\mathrm{LiCl}$ as the raw material. The appropriate quantity of these chemicals were weighted and mixed in agate mortar and were hand ground for about one hour. The weighted batches were heated in an electric furnace at $673 \mathrm{~K}$ for $1 / 2 \mathrm{~h}$ in porcelain crucibles to evaporate the ammonia then melted at $1273 \mathrm{~K}$ for $1 \mathrm{~h}$ with intermediate stirring to achieve the homogeneity of the melt. So, samples of the desired shape were obtained by quenching the melt at $623 \mathrm{~K}$ on a stainless steel mold for $2 \mathrm{~h}$ to eliminate the mechanical and thermal stresses produced during casting left to cool to room temperature. The $40 \mathrm{P}_{2} \mathrm{O}_{5}-20 \mathrm{ZnO}-(40-\mathrm{x}) \mathrm{Na}_{2} \mathrm{O}-\mathrm{xLi}_{2} \mathrm{O}$ glasses varied from 0 to $25 \mathrm{~mol}$. \% in steps of $5 \mathrm{~mol}$. \%. The prepared glass samples were polished by silicon carbide water proof abrasive papers of various grades ranging between 320 and 1000 to achieve a good optical transparency samples.

\subsection{Density measurements}

The density $(\rho)$ of the glass samples was determined at room temperature by the standard Archimedes principle using toluene as an immersion liquid $\left(\rho_{x}=0.86455 \mathrm{gm} . / \mathrm{cm}^{3}\right)$. The density was obtained from the relation,

$$
\rho=\left[\mathrm{W}_{\mathrm{a}} /\left(\mathrm{W}_{\mathrm{a}}-\mathrm{W}_{\mathrm{b}}\right)\right] \cdot \rho_{x},
$$

Where, $\mathrm{W}_{\mathrm{a}}$ is the weight of the glass sample in air, $\mathrm{W}_{\mathrm{b}}$ is the weight of the glass sample when immersed in toluene. The relative error in these measurements was about $1 \mathrm{mg} / \mathrm{cm}^{3}$. Also, the molar volume $\left(\mathrm{V}_{\mathrm{M}}\right)$ and the oxygen packing density (OPD) of the glass samples were calculated by using the molecular weight $(\mathrm{M})$ and density $(\rho)$ according to the following relations.

$$
\mathrm{V}_{\mathrm{M}}=\mathrm{M} / \rho
$$

and

$$
\mathrm{OPD}=1000 \cdot(\rho / M) \cdot n
$$

Where, $\mathrm{n}$ is the no. of oxygen atoms per formula unit. 


\subsection{X- ray Diffraction measurements (XRD)}

The amorphous nature of synthesized glass samples was checked by PANalytical X'Pert PRO diffractometer using $\mathrm{CuK} \alpha$ target of wavelength $1.5406 \mathrm{~A}^{\circ}$ and scanning rate $2 \% \mathrm{~min}$. XRD patterns were recorded in $2 \theta$ range between $4^{\circ}$ and $80^{\circ}$.

\subsection{Differential Thermal Analysis (DTA)}

The glass transition temperature $\left(\mathrm{T}_{\mathrm{g}}\right)$ and the crystallization temperature $\left(\mathrm{T}_{\mathrm{C}}\right)$, were evaluated for all the glass samples by using SDT Q600 V20.9 and scanned at a heating rate 10 ${ }^{0} \mathrm{C} / \mathrm{min}$.

\subsection{Infrared absorption measurements (FT-IR)}

The infrared absorption spectra of the $40 \mathrm{P}_{2} \mathrm{O}_{5}-20 \mathrm{ZnO}-(40-\mathrm{x}) \mathrm{Na}_{2} \mathrm{O}-\mathrm{xLi}_{2} \mathrm{O}$ glasses were measured at room temperature in the wave number range $400-4000 \mathrm{~cm}^{-1}$ by a Fourier transform computerized infrared spectrometer type, JASCO, FT/112 - 43, Japan. The prepared glasses were mixed with $\mathrm{KBr}$ in the ratio $2: 200 \mathrm{mg}$ glass powder : $\mathrm{KBr}$, respectively. Then the weighted mixture was subjected to a pressure 5 tons $/ \mathrm{cm}^{2}$ to produce clear homogeneous discs. The infrared absorption measurements were measured immediately after preparing the discs.

\subsection{Optical properties}

The optical absorption of the glass samples were recorded at room temperature using a double beam Cary 100 spectrophotometer (model UV-12) in the wavelength range 200-900 $\mathrm{nm}$. The uncertainty in the wavelength is found to be $\pm 1 \mathrm{~nm}$.

\section{Results and Discussion}

\subsection{Density and molar volume}

The values of density $(\rho)$ and molar volume $\left(\mathrm{V}_{\mathrm{M}}\right)$ of all the glass samples have been calculated and their values are displayed in Table 1. Variation of density and molar volume with mol. \% of $\mathrm{Li}_{2} \mathrm{O}$ is shown in Fig.1. Density is found an increase with increasing the content of $\mathrm{Li}_{2} \mathrm{O}$ in all glasses. This behavior of density is due to the electron negativity of $\mathrm{Zn}^{+}(1.65)$ is the most bigger than $\mathrm{Na}^{+}(0.93)$ and $\mathrm{Li}^{+}(0.98)$ which is responsible to compact the glass network and increases the density of glasses and also, the field strength of $\mathrm{Li}_{2} \mathrm{O}(0.21)$ attracts the oxygen ions more than $\mathrm{Na}_{2} \mathrm{O}$ (0.17), leading to an increase in the density [P.K. Jha et al (2015)]. The molar volume $\left(\mathrm{V}_{\mathrm{M}}\right)$ decreases linearly with increasing the $\mathrm{Li}_{2} \mathrm{O}$ content, this indicates a compact structure with less polymerization due to the shortened chain which confirming that the glass network became good compactable 


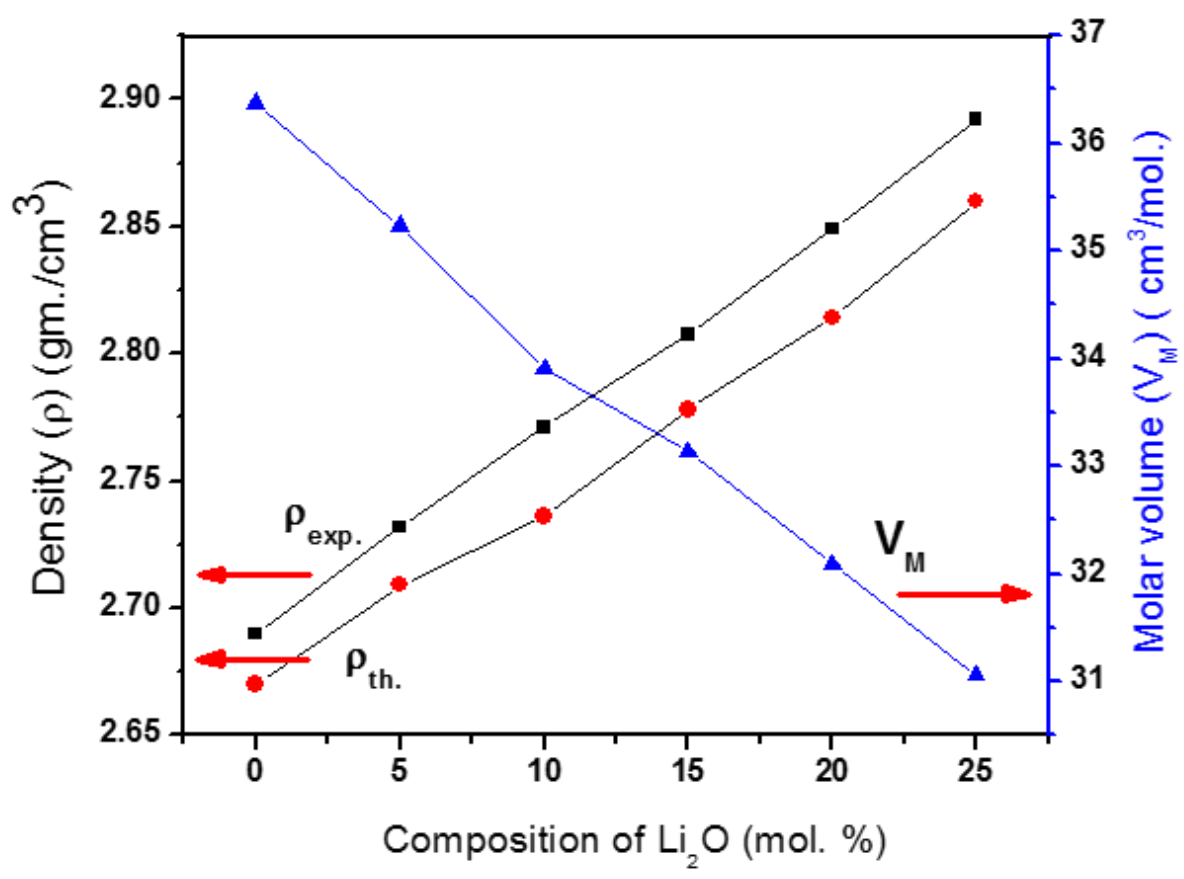

Fig.1. Variation of density $(\rho)$ and molar volume $\left(\mathrm{V}_{\mathrm{M}}\right)$ with composition of $\mathrm{Li}_{2} \mathrm{O}$ mol. $\%$.

Oxygen packing density (OPD) is a measure of the tightness of packing of the oxide network which increases linearly with increasing the $\mathrm{Li}_{2} \mathrm{O}$ content as in Fig.2. This also indicates that the structure more packed together.

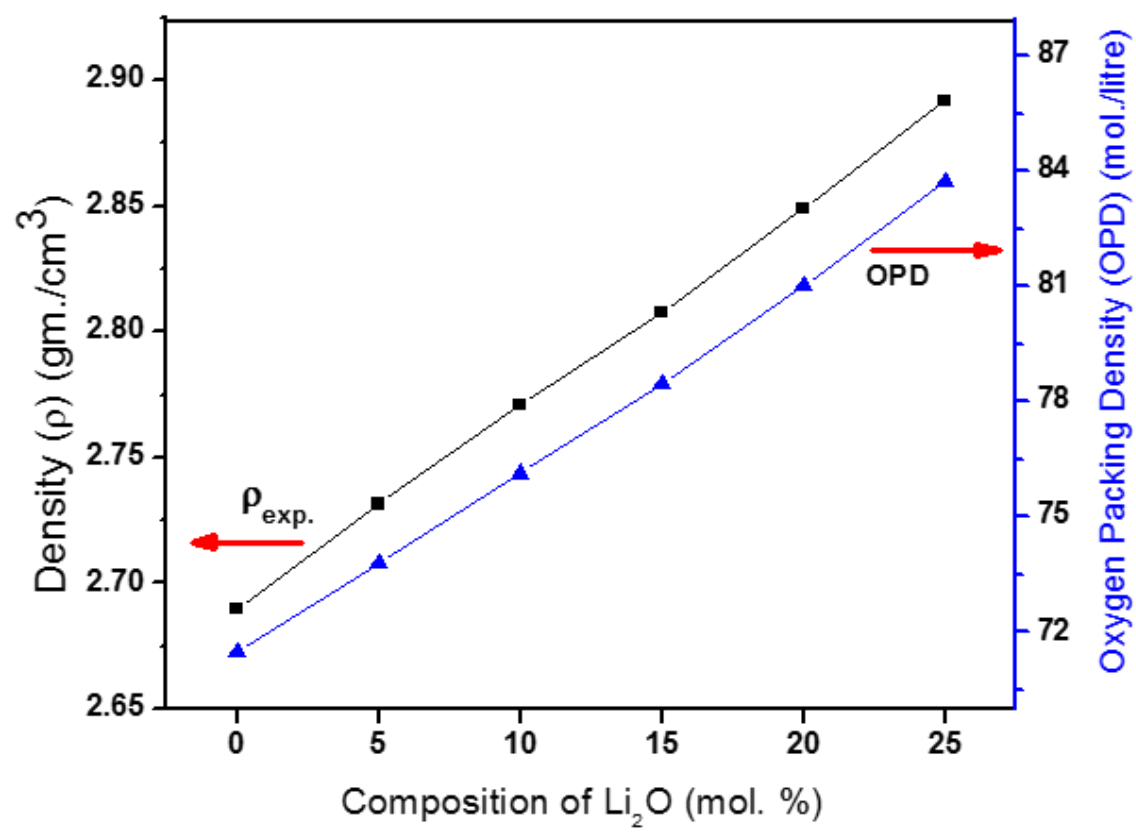

Fig.2. Variation of Oxygen packing density (OPD) with composition of $\mathrm{Li}_{2} \mathrm{O}$ mol. \% 
Table 1: Density $(\rho)$, molar volume $\left(\mathrm{V}_{\mathrm{M}}\right)$, and oxygen packing density (OPD) of the $40 \mathrm{P}_{2} \mathrm{O}_{5}-20 \mathrm{ZnO}-(40-\mathrm{x}) \mathrm{Na}_{2} \mathrm{O}-$ $\mathrm{xLi}_{2} \mathrm{O}$ glass samples.

\begin{tabular}{|c|c|c|c|c|}
\hline $\begin{array}{c}\text { Compositions of the } \\
40 \mathrm{P}_{2} \mathrm{O}_{5}-20 \mathrm{ZnO}-(40-\mathrm{x}) \\
\mathrm{Na}_{2} \mathrm{O}-\mathrm{xLi}_{2} \mathrm{O} \text { glasses } \\
(\mathrm{X} \text { in mol. } \%)\end{array}$ & $\begin{array}{c}\text { Theoretical } \\
\text { density } \\
\rho_{\text {th. }} \\
\left(\mathrm{gm} . / \mathrm{cm}^{3}\right)\end{array}$ & $\begin{array}{c}\text { Experimental } \\
\text { density } \\
\rho_{\text {exp. }} \\
\left(\mathrm{gm} . / \mathrm{cm}^{3}\right)\end{array}$ & $\begin{array}{c}\text { Molar } \\
\text { volume } \\
\mathrm{V}_{\mathrm{M}} \\
\left(\mathrm{cm}^{3} / \mathrm{mol} .\right)\end{array}$ & $\begin{array}{c}\text { Oxygen packing } \\
\text { density } \\
\text { OPD } \\
\text { (mol./litre) }\end{array}$ \\
\hline 0 & 2.680 & 2.690 & 36.37 & 71.48 \\
\hline 5 & 2.710 & 2.7316 & 35.232 & 73.795 \\
\hline 10 & 2.736 & 2.7711 & 33.906 & 76.132 \\
\hline 15 & 2.778 & 2.8077 & 33.134 & 78.468 \\
\hline 20 & 2.814 & 2.8492 & 32.089 & 81.025 \\
\hline 25 & 2.860 & 2.8920 & 31.059 & 83.712 \\
\hline
\end{tabular}

\subsection{X- ray Diffraction measurements (XRD)}

XRD Patterns of the $40 \mathrm{P}_{2} \mathrm{O}_{5}-20 \mathrm{ZnO}-(40-\mathrm{x}) \mathrm{Na}_{2} \mathrm{O}-\mathrm{xLi}_{2} \mathrm{O}$ glasses are shown in Fig.3. The presence of one broad humps in the range of $2 \theta$ from $15^{\circ}$ to $40^{\circ}$ confirming the amorphous nature of the glass.

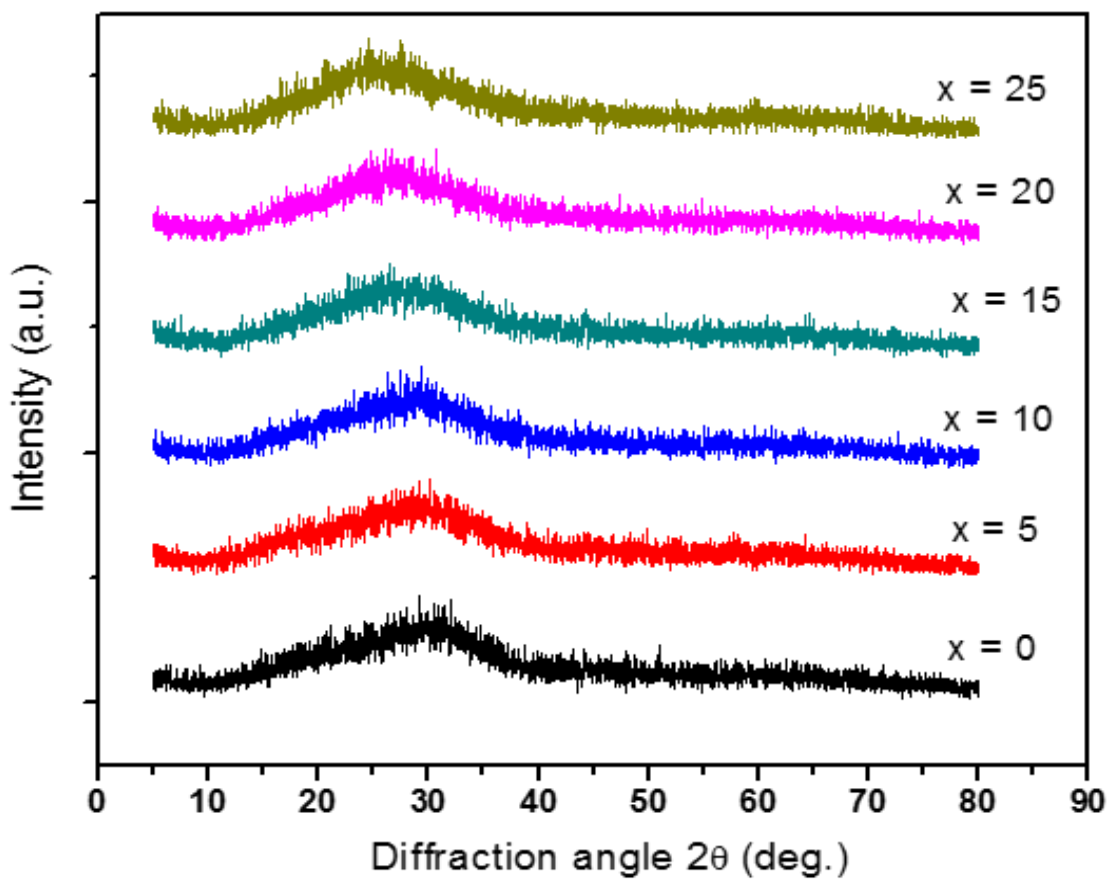

Fig.3. XRD patterns of the $40 \mathrm{P}_{2} \mathrm{O}_{5}-20 \mathrm{ZnO}-(40-\mathrm{x}) \mathrm{Na}_{2} \mathrm{O}-\mathrm{XLi}_{2} \mathrm{O}$ glasses with different concentrations of $\mathrm{Li}_{2} \mathrm{O}$ mol. $\%$ 


\subsection{Differential Thermal Analysis (DTA)}

The variation of DTA curves of the $40 \mathrm{P}_{2} \mathrm{O}_{5}-20 \mathrm{ZnO}-(40-\mathrm{x}) \mathrm{Na}_{2} \mathrm{O}-\mathrm{xLi}_{2} \mathrm{O}$ glasses with different concentration of $\mathrm{Li}_{2} \mathrm{O}(0 \leq \mathrm{x} \leq 25)$ are represented in Fig.4. The DTA curves are characterized by an endothermic peak corresponds to glass transition temperature $\left(\mathrm{T}_{\mathrm{g}}\right)$ and the exothermic peak which corresponds to the crystallization temperature $\left(\mathrm{T}_{\mathrm{C}}\right)$ [F. Wang et al (2015)].
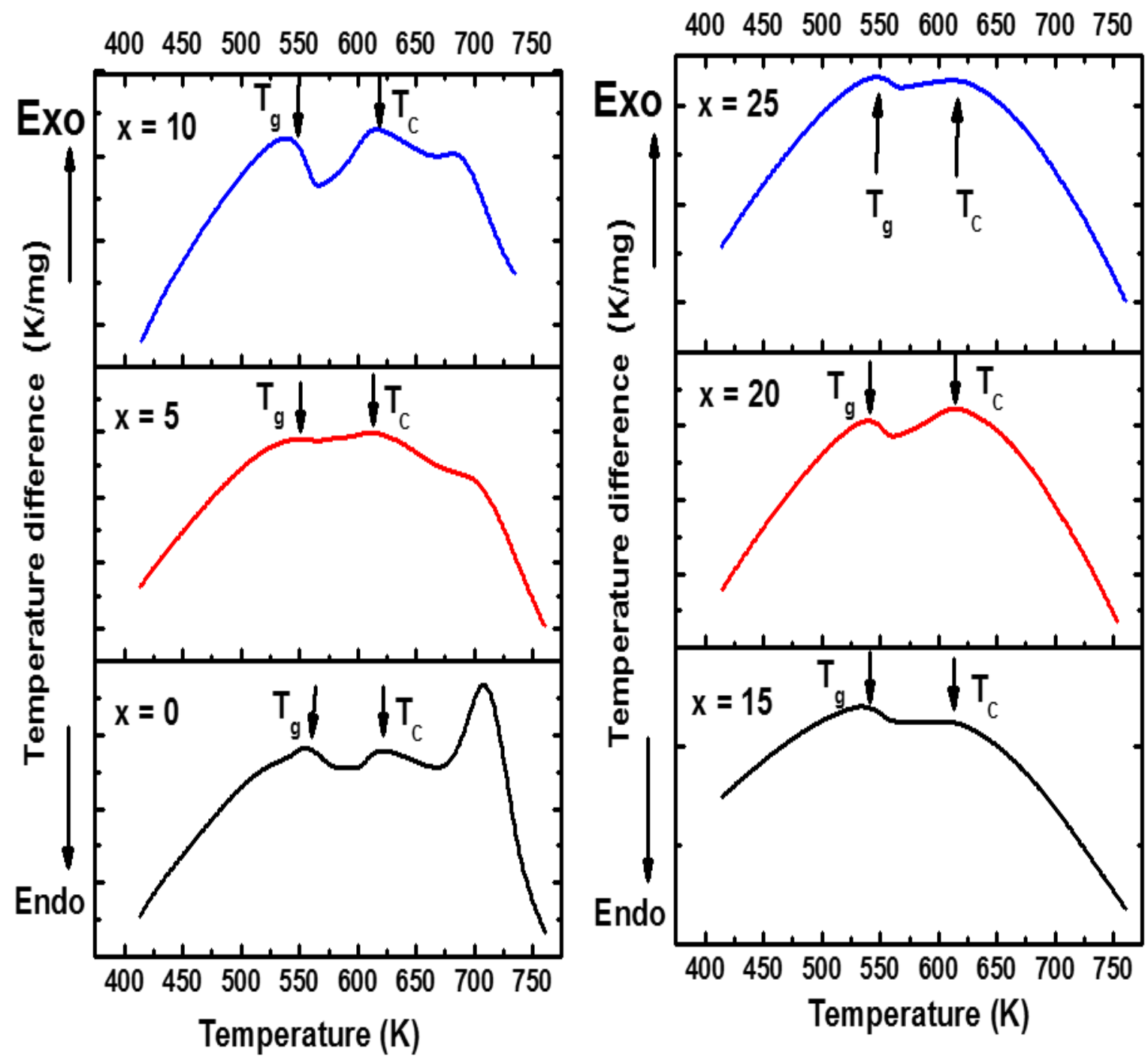

Fig. 4: DTA curves of the $40 \mathrm{P}_{2} \mathrm{O}_{5}-20 \mathrm{ZnO}-(40-\mathrm{x}) \mathrm{Na}_{2} \mathrm{O}-\mathrm{xLi} \mathrm{i}_{2} \mathrm{O}$ glasses with different concentrations of $\mathrm{Li}_{2} \mathrm{O}$ mol. \%

Fig. 5 shows the variation of $\mathrm{T}_{\mathrm{g}}$ and $\mathrm{T}_{\mathrm{c}}$ with $\mathrm{Li}_{2} \mathrm{O}$ contents with a heating rate of $10^{\circ} / \mathrm{min}$. It is observed from DTA measurements Table 2 that as the concentration of $\mathrm{Li}_{2} \mathrm{O}$ increases from 0 mol. \% to 25 mol.\% the glass transition temperature $\mathrm{T}_{\mathrm{g}}$ decreases because of $\mathrm{Li}_{2} \mathrm{O}$ is a strong modifier which creates non-bridging oxygens (NBOs). The non-bridging oxygens disrupt the 
long chains and break the chemical bonds [R. K. brow (2000)]. A parameter $(\Delta \mathrm{T})$ was obtained from $\Delta \mathrm{T}=\mathrm{T}_{\mathrm{C}}-\mathrm{T}_{\mathrm{g}}$ which, can be used in the measurements of the glass thermal stability $\mathrm{H}^{\prime}=\Delta \mathrm{T} /$ $\mathrm{T}_{\mathrm{g}}$ [H. Li. X. Liang et al (2014), $\quad$ Y. Liu, F. Song et al (2017)]. The characteristic temperatures are calculated and presented in Table $2 \&$ Fig.6. The value of glass thermal stability $\mathrm{H}^{\prime}$ for the glass sample with $\mathrm{Li}_{2} \mathrm{O}$ content $15 \mathrm{~mol}$. \% is found to be maximum, which indicates its highest thermal stability than other glasses.

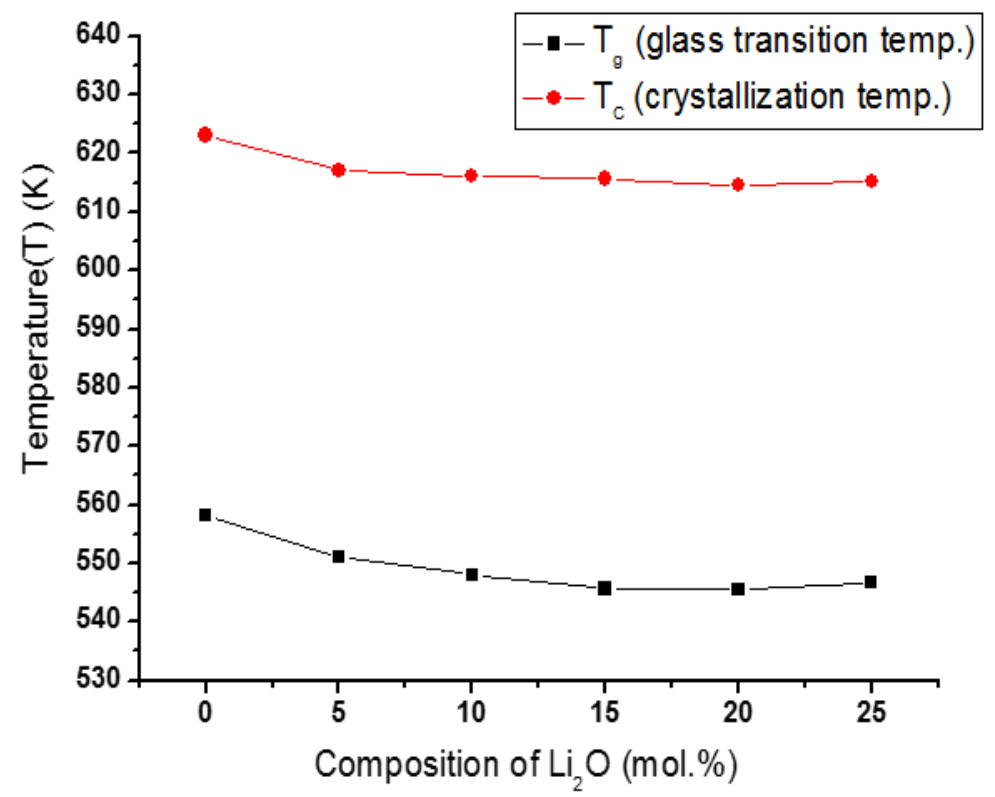

Fig. 5: Variation of Temperature $\left(\mathrm{T}_{\mathrm{g}} \& \mathrm{~T}_{\mathrm{C}}\right)$ with composition of $\mathrm{Li}_{2} \mathrm{O}$ mol. \%

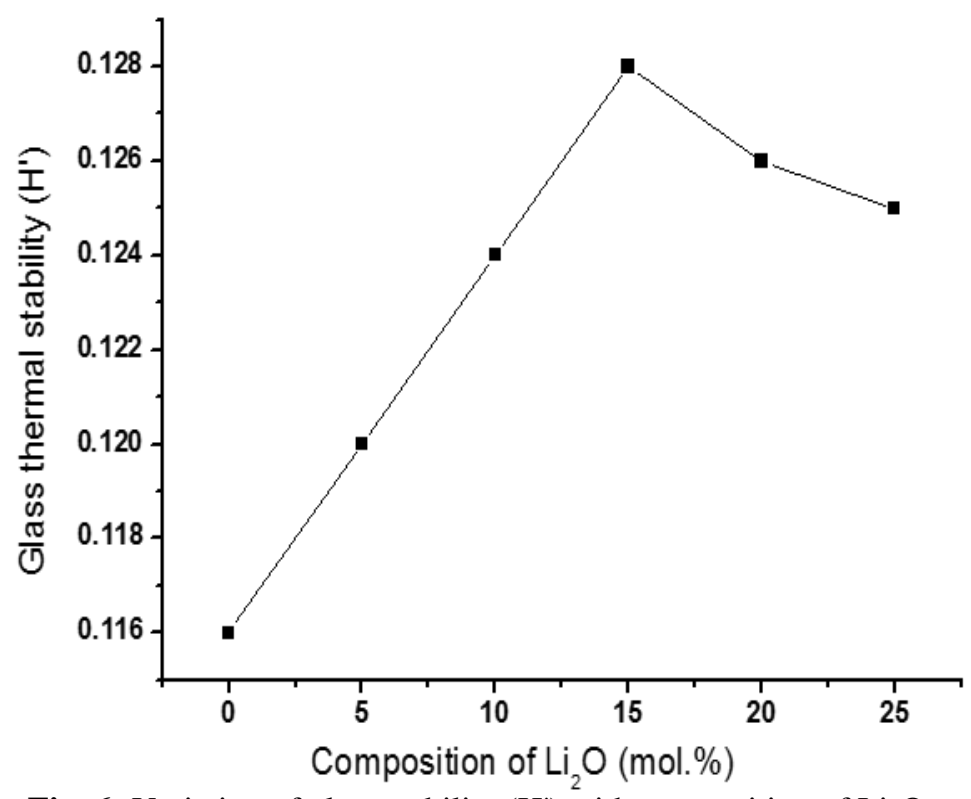

Fig. 6: Variation of glass stability (H') with composition of $\mathrm{Li}_{2} \mathrm{O}$ mol. \% 
Table 2: Thermal constants observed from DTA for the $40 \mathrm{P}_{2} \mathrm{O}_{5}-20 \mathrm{ZnO}-(40-\mathrm{x}) \mathrm{Na}_{2} \mathrm{O}-\mathrm{xLi}_{2} \mathrm{O}$ glass samples.

\begin{tabular}{|cccc|}
\hline $\begin{array}{c}\text { Glass sample } \\
(\mathrm{X} \text { in mol. \% })\end{array}$ & $\begin{array}{c}\text { Glass transition temp. } \\
\mathrm{T}_{\mathrm{g}}(\mathrm{K})\end{array}$ & $\begin{array}{c}\text { Crystallization } \\
\text { temp. } \\
\mathrm{T}_{\mathrm{C}}(\mathrm{K})\end{array}$ & $\begin{array}{c}\text { Glass thermal stability } \\
\mathrm{H}^{\prime}=\Delta \mathrm{T} / \mathrm{T}_{\mathrm{g}}\end{array}$ \\
\hline 0 & 558.08 & 623.01 & 0.116 \\
5 & 551.15 & 617.1 & 0.120 \\
10 & 548.02 & 616.1 & 0.124 \\
15 & 545.6 & 615.6 & 0.128 \\
20 & 545.5 & 614.6 & 0.126 \\
25 & 546.7 & 615.2 & 0.125 \\
\hline
\end{tabular}

\subsection{Infrared absorption measurements (FTIR)}

FTIR spectra of the $40 \mathrm{P}_{2} \mathrm{O}_{5}-20 \mathrm{ZnO}-(40-\mathrm{x}) \mathrm{Na}_{2} \mathrm{O}-\mathrm{xLi}_{2} \mathrm{O}$ glasses with different concentration of $\mathrm{Li}_{2} \mathrm{O}$ mol.\% in the frequency range of $400-4000 \mathrm{~cm}^{-1}$ are shown in Fig.7 and tabulated in Table 3. The FTIR results reveal that the glasses structure network mainly consist of $(\mathrm{O}=\mathrm{P}-\mathrm{O})$ in $\mathrm{Q}^{3},(\mathrm{P}-\mathrm{O}-\mathrm{P})$ in $\mathrm{Q}^{1}$ and $\mathrm{Q}^{2}, \mathrm{PO}_{2}$ in $\mathrm{Q}^{2}$ and $\mathrm{PO}_{4}{ }^{3-}$ in $\mathrm{Q}^{0}$. If the modifier content increases in the phosphate matrix, phosphate structural units may be changes from $\mathrm{Q}^{3} \rightarrow \mathrm{Q}^{2} \rightarrow$ $\mathrm{Q}^{1} \rightarrow \mathrm{Q}^{0}$ [P. K. Jha et al (2015)]. The change in structural units from $\mathrm{Q}^{3}$ to $\mathrm{Q}^{0}$ provides nonbridging bonds with less polymerization, which forms rigid structures due to the shortened chain length. This observation is confirmed by density and molar volume discussion of the investigated glasses. It is observed also from Fig.8 that bonds of $(\mathrm{P}-\mathrm{O}-\mathrm{P})$ asymmetric and symmetric stretching modes shift to higher frequency as the $\mathrm{Li}_{2} \mathrm{O}$ mol.\% content increases. This shift can be explained to the increase in covalent character of $(\mathrm{P}-\mathrm{O}-\mathrm{P})$ bonds and indicates that $(\mathrm{P}-\mathrm{O}-\mathrm{P})$ bonds are strengthened as $\mathrm{Li}_{2} \mathrm{O}$ substituted for $\mathrm{Na}_{2} \mathrm{O}$ and $\mathrm{P}_{2} \mathrm{O}_{5}$. 


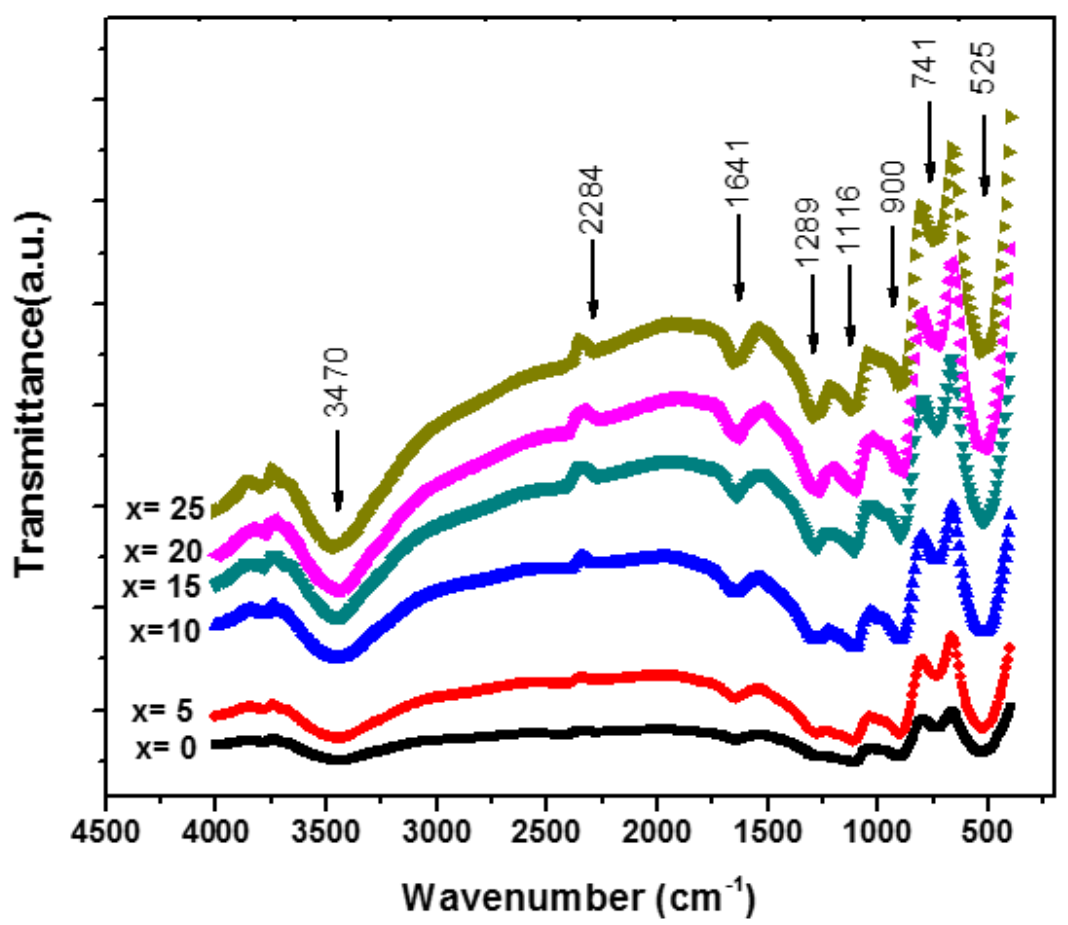

Fig. 7: FTIR spectra of the $40 \mathrm{P}_{2} \mathrm{O}_{5}-20 \mathrm{ZnO}-(40-\mathrm{x}) \mathrm{Na}_{2} \mathrm{O}-\mathrm{xLi}_{2} \mathrm{O}$ glasses with different concentrations of $\mathrm{Li}_{2} \mathrm{O}$ mol. \%

The shift of these bands at a higher region $\left(520.91 \rightarrow 533.52 \mathrm{~cm}^{-1}\right)$ and $(732.17 \rightarrow$ $765.79 \mathrm{~cm}^{-1}$ ), designates the bending vibration of $\mathrm{O}=\mathrm{P}-\mathrm{O}$ bonds, and $\mathrm{P}-\mathrm{O}-\mathrm{P}$ symmetric stretching group in $\mathrm{Q}^{1}$ structural units respectively [C. Dayanand et al (1996),Y. M. Lai et al (2011)]. The band between $\quad\left(895.51 \rightarrow 906.09 \mathrm{~cm}^{-1}\right)$ corresponding to asymmetric stretching vibration of $\mathrm{P}-\mathrm{O}-\mathrm{P}$ groups in $\mathrm{Q}^{2}$ structural unit [G.V. Rao et al (2014)]. There are two weak peaks (993.12 and $1002.69 \mathrm{~cm}^{-1}$ ) which appear in $\mathrm{x}=15 \% \& 20 \%$ of $\mathrm{Li}_{2} \mathrm{O}$ content and disappear in lower \& higher concentration. This band is due to $\mathrm{PO}_{4}^{3-}$ symmetric stretching groups in $\mathrm{Q}^{0}$ structural unit [C. Dayanand et al (1996)]. Also, the band $\left(1108.36 \rightarrow 1125.65 \mathrm{~cm}^{-1}\right)$ is due to $\mathrm{PO}_{4}^{3-}$ symmetric stretching groups in $\mathrm{Q}^{0}$ structural unit

[R. L. Frost et al (2013)]. The asymmetric stretching modes of $\mathrm{PO}_{2}$ group in $\mathrm{Q}^{2}$ structural unit are appeared in $(1270.64 \rightarrow$ $1302.44 \mathrm{~cm}^{-1}$ ) [Y. Tsunawaki (1981)]. It can be observed that in all glasses that these bands $\left(1640.99 \rightarrow 1645.18 \mathrm{~cm}^{-1}\right)$ and $\left(2263.33 \rightarrow 2280.71 \mathrm{~cm}^{-1}\right)$ are due to the bending vibration of $\mathrm{H}_{2} \mathrm{O}$ molecules [F. H. Elbatal (2008), F. H. Elbatal (2011)]. A certain shift in the band $\left(3442 \rightarrow 3472 \mathrm{~cm}^{-1}\right)$ presents in all the investigated glass samples is associated with the oscillations of symmetric stretching of $\mathrm{O}-\mathrm{H}$ group [N. S. Hussain et al (2004)]. A certain shift in this band at higher region $\left(3442 \rightarrow 3472 \mathrm{~cm}^{-1}\right)$ designates the enhancement of $\mathrm{OH}$ group. 
Table 3: FTIR bands of the $40 \mathrm{P}_{2} \mathrm{O}_{5}-20 \mathrm{ZnO}-(40-\mathrm{x}) \mathrm{Na}_{2} \mathrm{O}-\mathrm{xLi}_{2} \mathrm{O}$ glasses $(0 \leq \mathrm{x} \leq 25$ mol. \%)

\begin{tabular}{|c|c|c|c|c|c|c|}
\hline \multicolumn{5}{|c|}{ Wave numbers $\left(\mathrm{cm}^{-1}\right)$} & \multicolumn{2}{|r|}{ Assignments } \\
\hline$X=0$ & $X=5$ & $X=10$ & $X=15$ & $X=20$ & $X=25$ & \\
\hline 528.36 & 520.91 & 520.96 & 525.22 & 531.0 & 533.52 & Bending vibration of $(\mathrm{O}=\mathrm{P}-\mathrm{O})$ bond \\
\hline 732.17 & 734.68 & 733.68 & 741.92 & 754.66 & 765.79 & $\begin{array}{c}\text { Symmetric stretching of }(\mathrm{P}-\mathrm{O}-\mathrm{P}) \text { group in } \mathrm{Q}^{1} \\
\text { structural unit }\end{array}$ \\
\hline 903.05 & 897.75 & 895.51 & 900.47 & 901.34 & 906.09 & $\begin{array}{l}\text { Asymmetric stretching of }(\mathrm{P}-\mathrm{O}-\mathrm{P}) \text { group in } \\
\qquad \mathrm{Q}^{2} \text { structural unit }\end{array}$ \\
\hline---- & ---- & ---- & 993.19 & 1002.69 & ---- & Symmetric stretching of $\left(\mathrm{PO}_{4}^{3-}\right)$ group in $\mathrm{Q}^{0}$ \\
\hline 1109.27 & 1108.36 & 1109.80 & 1116.19 & 1116.13 & 1125.65 & $\begin{array}{c}\text { structural unit } \\
\text { Symmetric stretching of }\left(\mathrm{PO}_{4}^{3-}\right) \text { group in } \mathrm{Q}^{0}\end{array}$ \\
\hline 1270.64 & 1280.09 & 1286.39 & 1289.60 & 1287.06 & 1302.44 & $\begin{array}{c}\text { structural unit } \\
\text { Asymmetric stretching of }\left(\mathrm{PO}_{2}\right) \text { group in } \mathrm{Q}^{2} \\
\text { structural unit }\end{array}$ \\
\hline 1645.18 & 1643.06 & 1643.78 & 1641.72 & 1640.99 & 1641.50 & Bending vibration $\mathrm{H}_{2} \mathrm{O}$ molecule \\
\hline 2276.43 & 2280.71 & 2263.33 & 2284.15 & 2285.92 & 2280.54 & Bending vibration of $\left(\mathrm{H}_{2} \mathrm{O}\right)$ molecule \\
\hline 3442.01 & 3458.42 & 3460.69 & 3470.57 & 3466.15 & 3472.41 & $\begin{array}{l}\text { Oscillations due to symmetric stretching of } \\
\qquad \mathrm{O}-\mathrm{H} \text { group }\end{array}$ \\
\hline
\end{tabular}

\subsection{Optical properties}

The optical measurements are productive tools for understanding the band structure and evaluating the band gap width and optical parameters of both ordered and disordered materials.

Fig. 8 (a, b) show the absorbance which has been measured for the $40 \mathrm{P}_{2} \mathrm{O}_{5}-20 \mathrm{ZnO}-(40-\mathrm{x}) \mathrm{Na}_{2} \mathrm{O}-\mathrm{xLi} \mathrm{i}_{2} \mathrm{O}$ glasses. The absorbance is related to the absorption coefficient $(\alpha)$ and the thickness of the sample (t) through the relation eqn. (4):

$$
\alpha(v)=(1 / t) \cdot \ln \left(\frac{1}{T}\right)=(1 / t) \cdot \ln \mathrm{A}
$$

Where, $\mathrm{T}$ is the transmittance, $\mathrm{t}$ is the thickness of the glass sample, and $\mathrm{A}$ is the absorbance.

The absorption coefficient for the glass samples with different concentration has been calculated as shown in Fig. 9 (a, b). The relationship between the absorption coefficient and the incident photon energy (hv) is governed by the relation [J.I. Pankove (1971), J. Tauc (1974)]:

$$
\alpha(v)=\text { const } \cdot\left(h v-E_{g}\right)^{n} / h v
$$



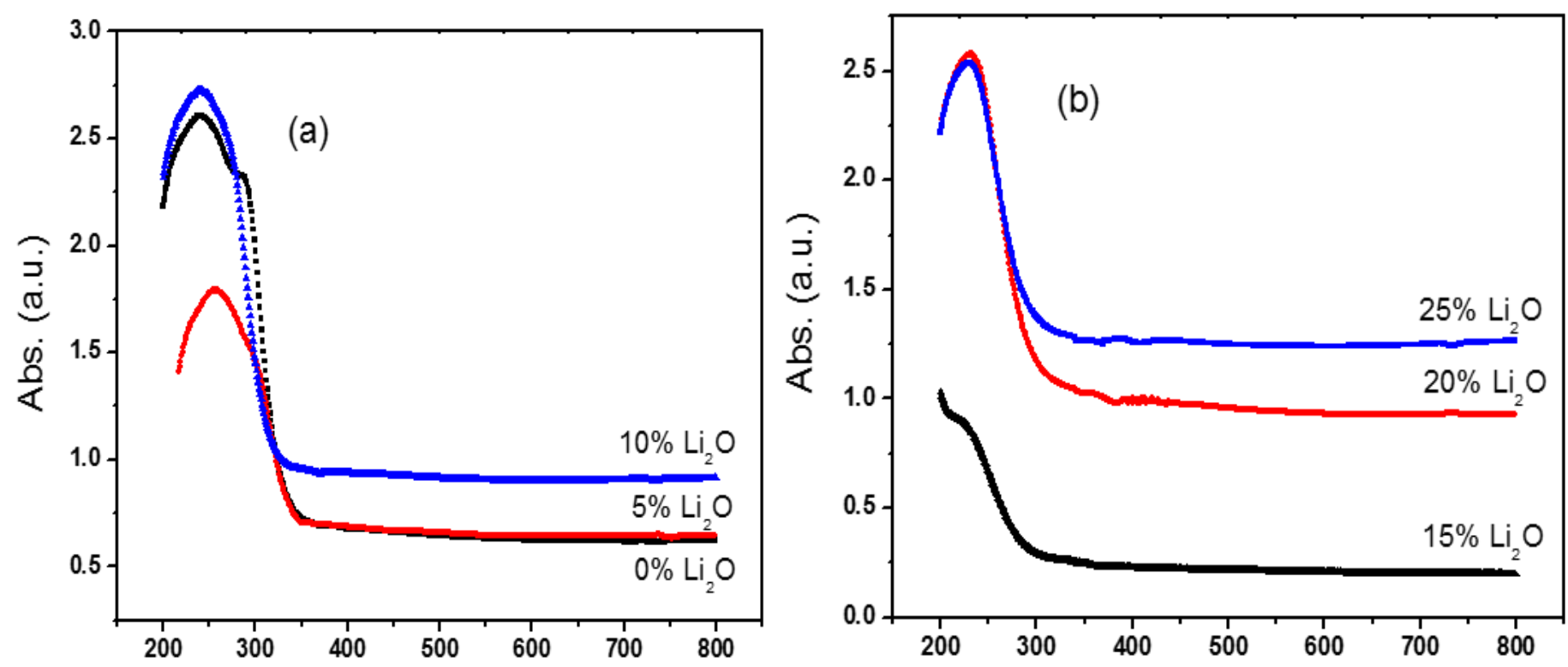

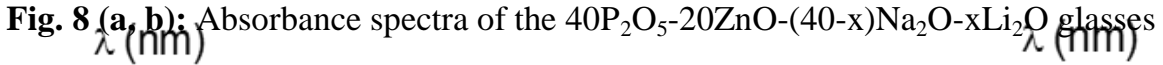

with different concentrations of $\mathrm{Li}_{2} \mathrm{O}$ mol. \%.
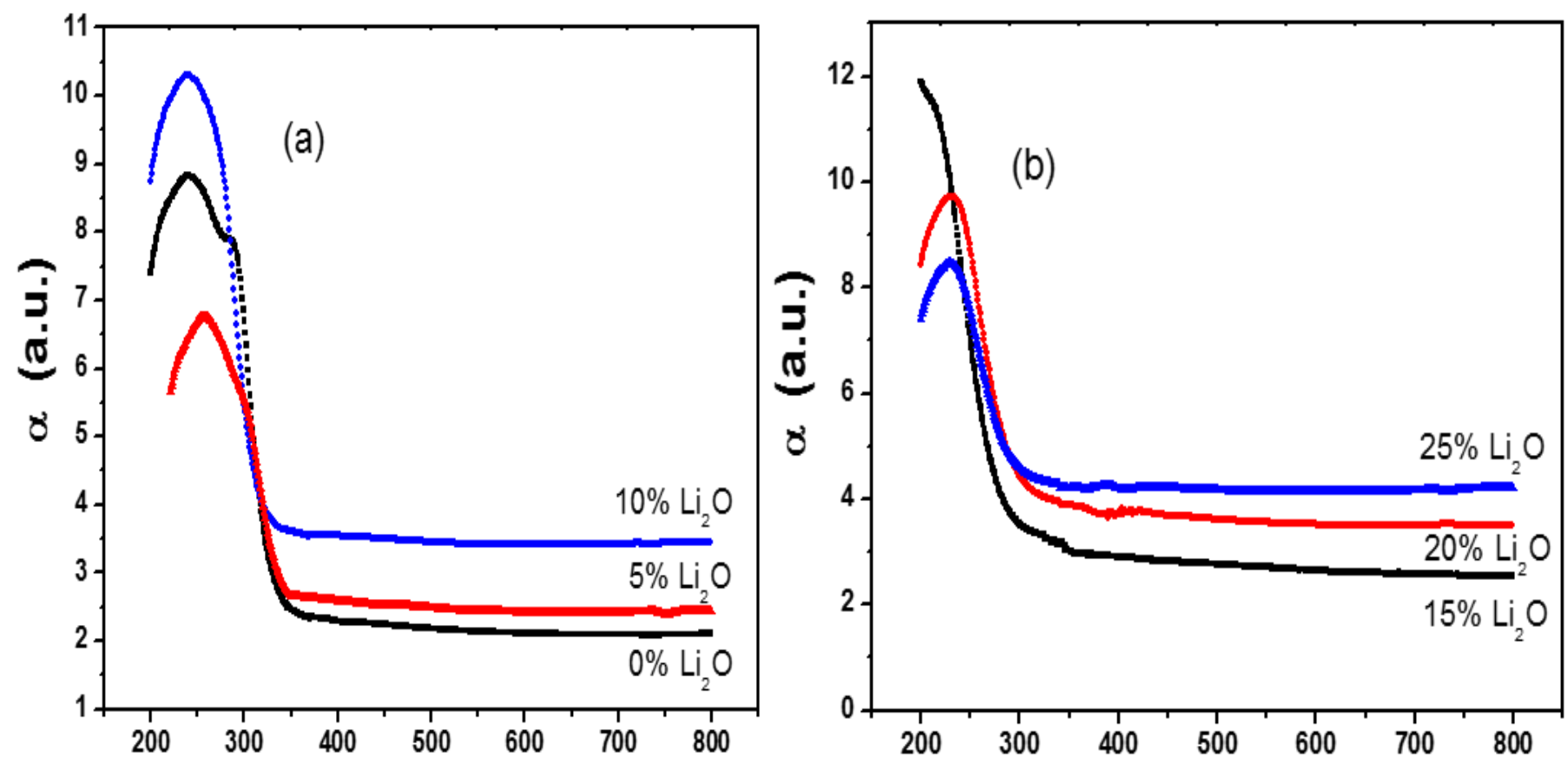

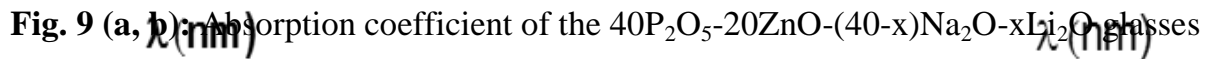

with different concentrations of $\mathrm{Li}_{2} \mathrm{O}$ mol. \%.

where, the const. is dependent on the transition probability, $\mathrm{E}_{\mathrm{g}}$ is the width of the band gap and $\mathrm{n}$ is an index that characterizes the optical absorption processes in all investigated glasses and is equal to $\quad 2,1 / 2,3,3 / 2$ for an indirect allowed, direct allowed, indirect forbidden, and direct forbidden transition respectively [A.F. Qasrawi (2005)]. For the amorphous material is usually corresponding to the indirect transition hence $(\alpha h v)^{1 / 2}$ was plotted against hv as shown in Fig. 10 $(\mathrm{a}, \mathrm{b})$ for the $40 \mathrm{P}_{2} \mathrm{O}_{5}-20 \mathrm{ZnO}-(40-\mathrm{x}) \mathrm{Na}_{2} \mathrm{O}-\mathrm{xLi}_{2} \mathrm{O}$ glasses. So, the optical band gap energy was 
calculated for such glasses by linear fitting of the high absorption regions. The intersection on hv - axis corresponded to the optical band gap $\mathrm{E}_{\mathrm{g}}$ with $(\alpha \mathrm{hv})^{1 / 2}$ equals zero. The relation between $\ln (\alpha)$ and ho gives the Urbach energy which is the width of the tail of the localized states in the band gap according to the relation:

$$
\begin{aligned}
& \left.\alpha=\text { const . exp. ( hv / } E_{u}\right) \\
& \ln (\alpha)=\left(h v / E_{u}\right)-\text { const }
\end{aligned}
$$

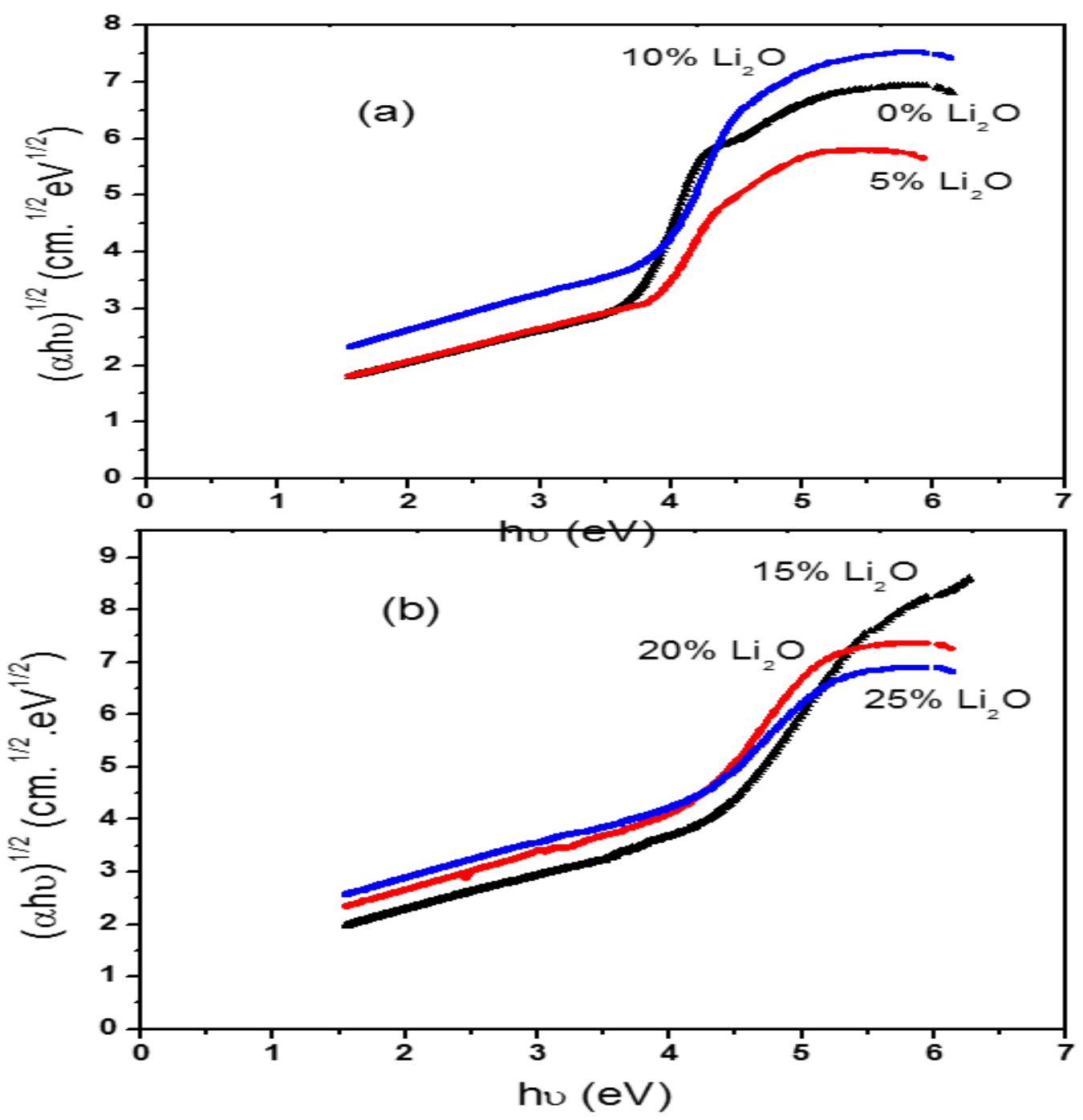

Fig. 10 (a, b): variation of $(\alpha h v)^{1 / 2}$ versus hv for the $40 \mathrm{P}_{2} \mathrm{O}_{5}-20 \mathrm{ZnO}-(40-\mathrm{x}) \mathrm{Na}_{2} \mathrm{O}-\mathrm{xLi}_{2} \mathrm{O}$ glasses with different concentrations of $\mathrm{Li}_{2} \mathrm{O}$ mol. \%. 

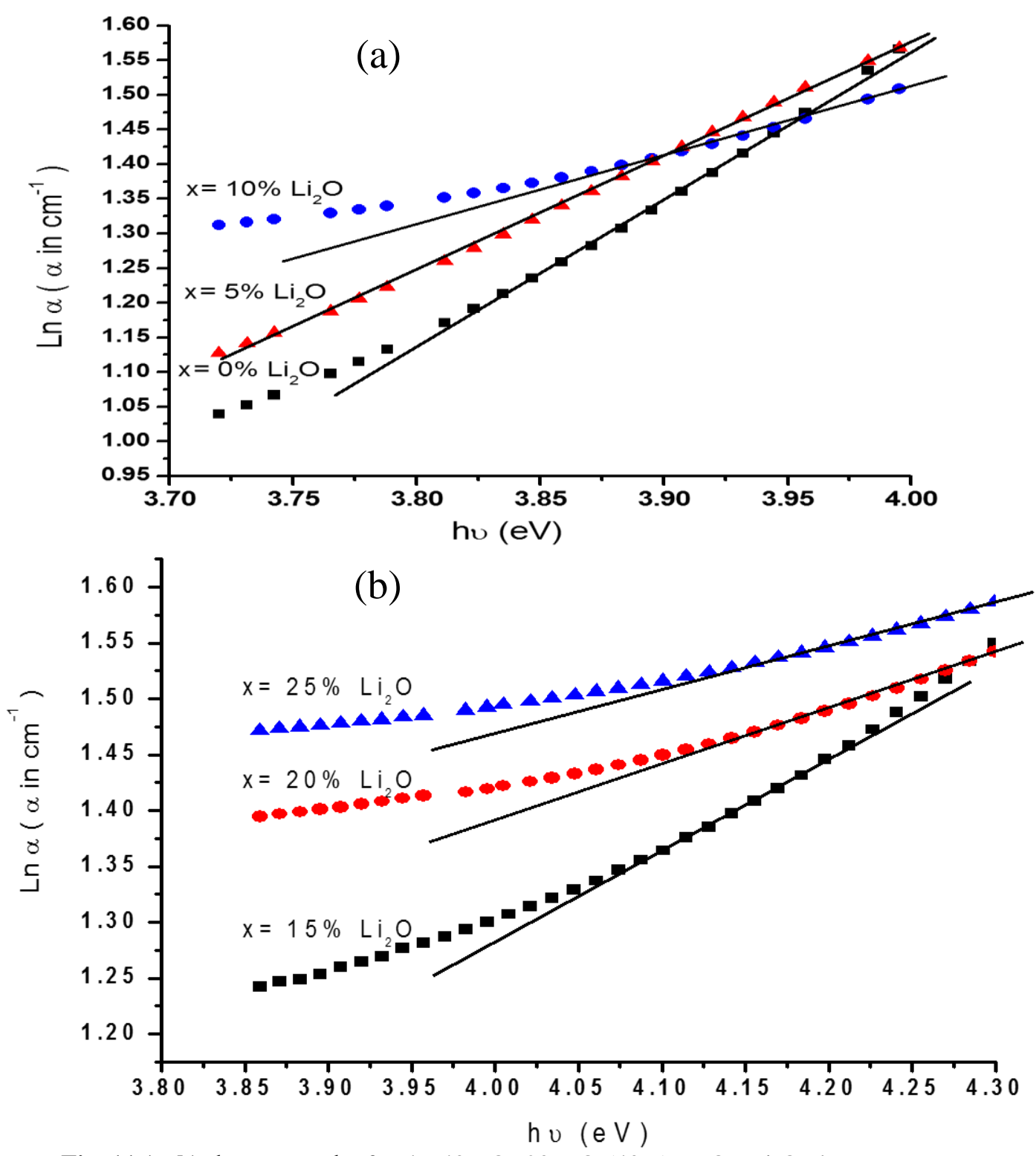

Fig. 11 (a, b): $\ln \alpha$ versus hv for the $40 \mathrm{P}_{2} \mathrm{O}_{5}-20 \mathrm{ZnO}-(40-\mathrm{x}) \mathrm{Na}_{2} \mathrm{O}-\mathrm{xLi}_{2} \mathrm{O}$ glasses

with different concentrations of $\mathrm{Li}_{2} \mathrm{O}$ mol. \%.

In the present study, Urbach energy can be presented as in Fig. 11 (a, b) for samples contain $\mathrm{Li}_{2} \mathrm{O}\left(\mathrm{x}=0,5,10,15,20,25 \mathrm{~mol}\right.$. \%). It is found that the energy gap $\mathrm{E}_{\mathrm{g}}$ decreases from 3.33 to $2.64 \mathrm{eV}$ by increasing $\mathrm{Li}_{2} \mathrm{O}$ content and Urbach energy increases from 0.46 to $2.4 \mathrm{eV}$ which are represented in Fig. 12. 


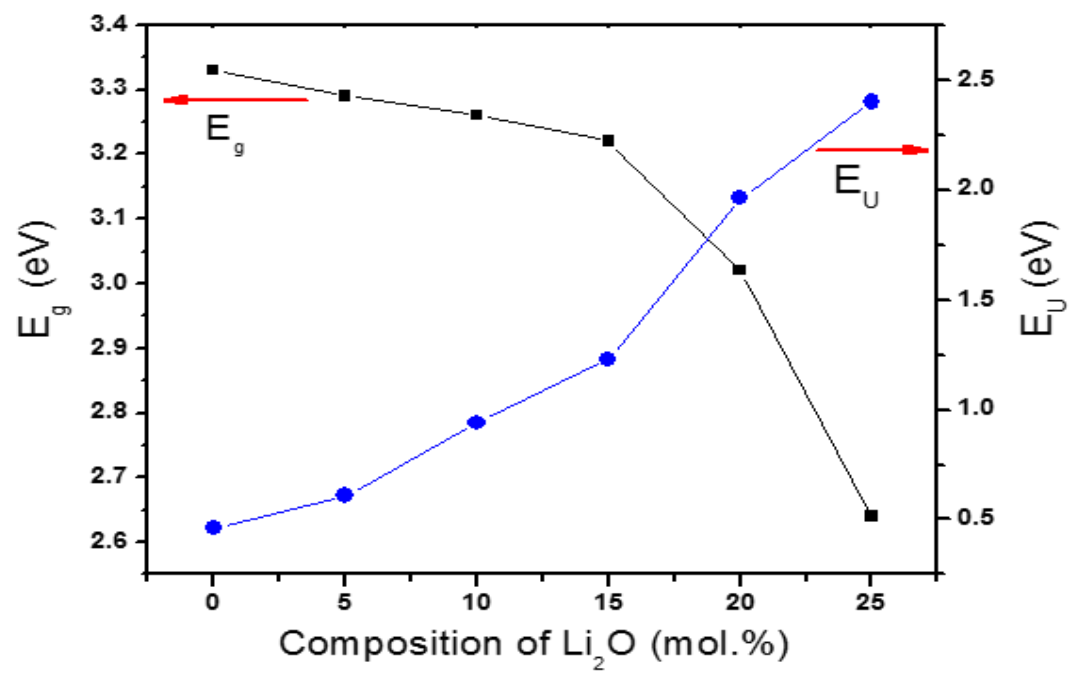

Fig. 12: Optical energy gap \& Urbach energy for the $40 \mathrm{P}_{2} \mathrm{O}_{5}-20 \mathrm{ZnO}-(40-\mathrm{x}) \mathrm{Na}_{2} \mathrm{O}-\mathrm{xLi} \mathrm{Li}_{2} \mathrm{O}$ glasses with different concentrations of $\mathrm{Li}_{2} \mathrm{O}$ (mol. \%).

\section{Conclusion}

The structural and optical properties of the $40 \mathrm{P}_{2} \mathrm{O}_{5}-20 \mathrm{ZnO}-(40-\mathrm{x}) \mathrm{Na}_{2} \mathrm{O}-\mathrm{xLi}_{2} \mathrm{O}$ glasses $\left(0 \leq \mathrm{x} \leq 25 \mathrm{~mol}\right.$. $\left.\% \mathrm{Li}_{2} \mathrm{O}\right)$ prepared by conventional melt quenching technique were investigated. The results show that all prepared glasses are amorphous in nature. The replacement of $\mathrm{Na}_{2} \mathrm{O}$ by $\mathrm{Li}_{2} \mathrm{O}$ decreases the glass transition temperature $\left(\mathrm{T}_{\mathrm{g}}\right)$. The glass sample with $\mathrm{Li}_{2} \mathrm{O}$ content 15 mol. \% exhibits highest thermal stability. It is found

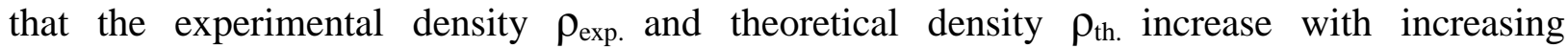
$\mathrm{Li}_{2} \mathrm{O}$ mol. \%, while the molar volume exhibits opposite trend to that of density. The FTIR results reveal that the glasses structure network mainly consists of $\mathrm{Q}^{3}, \mathrm{Q}^{2}, \mathrm{Q}^{1}$ and $\mathrm{Q}^{0}$ structural units. The phosphate structural units may be changes from $\mathrm{Q}^{3}$ to $\mathrm{Q}^{0}$ by increasing the modifier content and provides nonbridging bonds with less polymerization. 


\section{References}

A. Bhide, K. Hariharan, Mater. Chem. Phys.105 (2007) 213.

A.F. Qasrawi, Cryst. Res. Technol., 40 (2005) 610-614.

A. V. Chandrasekhar, A. Radhapathy, B. I. Reddy, Opt. Mater. 22 (2003) 215.

A. Yamano, M. Morishita, G. Park, T. Sakamoro, H. Yamauchi, T. Nagakane, M.Ohji,

A. Sakamoto, T. Sakai, J. Electrochem. Soc. 161 (2014) A1094-A1099.

C. Dayanand, G. Bhikshamaiah, V. Jaya Tyagaraju, M. Salagram, A.S.R. Krishna Murthy, J. Mater. Sci. Lett. 31 (1996) 1945.

D. Carta, J. Knowles, P. Guerry, M. Smith, R. New. Port, J. Mater. Chem., 19 (2009) 150158.

D. E. Day, Z. Wu, C. S. Ray and P. Hrna, J. Non-Cryst. Solids, 241, 1 (1998).

D. D. Ramteke, R. E. Kroon, H. C. Swart, J. Non-Cryst. Solids 457 (2017) 157-163.

F. H. Elbatal, J. Mater. Sci. 43 (2008) 1070-1079.

F. H. Elbatal, M. A. Marzouk, A. M. Abdelghany, J. Non-Cryst. Solids 357 (2011) 1027-1036.

F. Wang, Q. Liao, Y. Dai, H. Zhu, Mater. Chem. Phys, 166 (2015) 215-222.

G.V. Rao, H. D. Shashikala, J. Adv. Ceram. 3 (2014) 109-116.

H. Li. X. Liang, C. Wang, H. Yu. Z. Li. S. Yang, J. Mol. Struct. 1076 (2014) 592-599.

I. Abrahams, E. Hadzifejzovic, Solid State Ionic 134 (2000) 249.

J. Tauc, Amorphous and Liquid Semiconductors, New York: Plenum Ch. 4, 1974.

J.I. Pankove, Optical Processes in Semiconductors, New Jersey, Prentice-Hall, 1971.

N. S. Hussain, M.A. Lopes, J. D. Santos, Mater. Chem. Phys. 88 (2004) 5.

Nehal Aboulfotoh, Yahia El bashar, Mohamed Ibrahem, Mohamed El Okr, Ceramics International 40 (2014) 10305-10399.

P. K. Jha, O. P. Pandey, K. Singh, J. Mol. Struct. 1094 (2015) 174-182.

P. M. V. Teja, C. Rajyasree, P. S. Rao, A. R. Babu, C. Tirupataiah, D. K. Rao, J. Mol. Struct. 1014 (2012) 119-125.

P.K. Jha et al, Journal of Molecular Structure 1094 (2015) 174 -182.

Paramjyot Komar Jha, O. P. Pandey, K. Singh, J. Mol. Struct. 1094 (2015) 174-182. 
R. K. Brow, D. R. Tallant, S. T. Myers and C. C. Phifer, J. Non- Cryst. Solids, 191, 45, (1995).

R. L. Frost, Y. Xi. R. Scholz, F. M. Belotti, M. C. Filho, Spect. Lett. 46 (2013) 415-420.

R. K. Brow, J. Non-Cryst. Solids, 1 (2000) 263-264.

S. T. Reis, M. Karabulut and D. E. Day, J. Non-Cryst. Solids, 292, 150 (2001).

Samir Y. Marzouk, Materials Chemistry and Physics 114 (2009) 188-193.

Y. Liu, F. Song, G. Jia, Y. Zhang, Y. Tang, Results in Physics 7 (2017) 1987-1992.

Y. M. Lai, X. F. Liang, S. Y. Yang, J. X. Wang, L. H. Cao, B. Dai, J. Mol. Struct. 992 (2011) 84-88.

Y. Tsunawaki, J. Non-Cryst. 44 (1981) 369-378.

Yahia H. Elbashar, Ali M. Badr, Haron A. Elshaikh, Ahmed G. Mostafa, Ali M. Ibrahim, Processing and Application of Ceramics 10 (4) (2016) 277-286. 


\title{
الملخص باللغة العربية
}

\section{الخواص التركيبية و الضوئية لزجاج أكسيد فوسفات الزنك الصوديوم الليثوم}

\author{
a نجلاء فتحى عثمان، b محمد محمود العقر، c ليلى ابراهيم سليمان، d حمدية عبد الحميد زايد

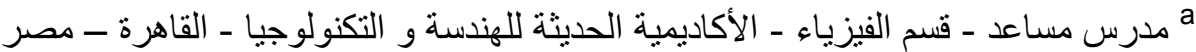

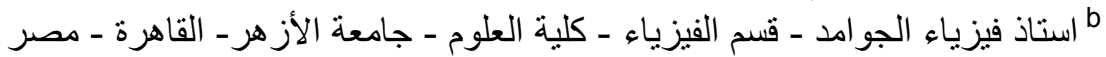

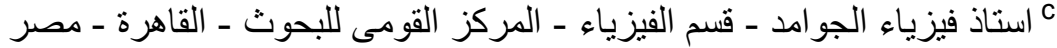

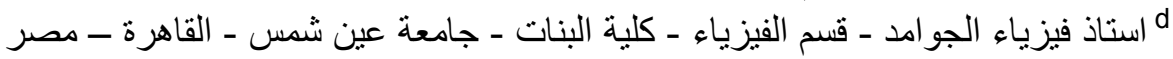

فى هذا البحث تم تحضير زجاج شفاف من (0 mol. \% sX $\leq 25$ mol. \%)

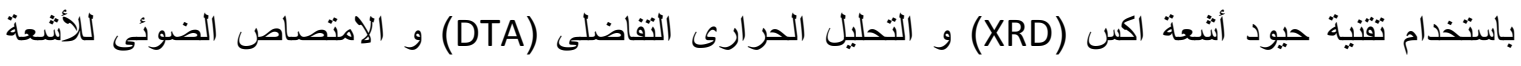

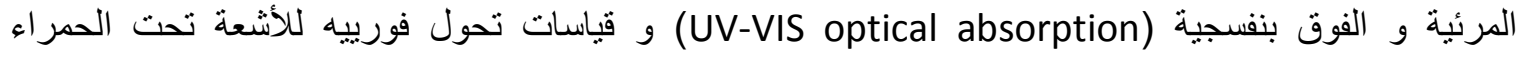

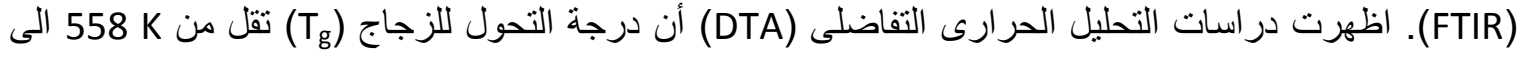

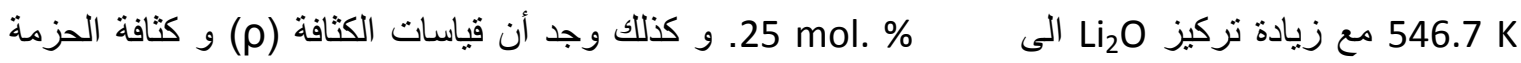

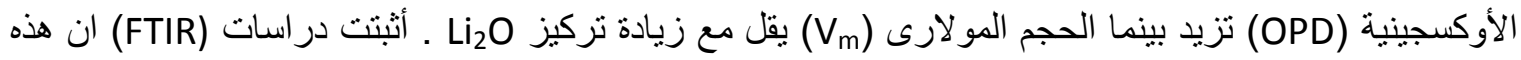

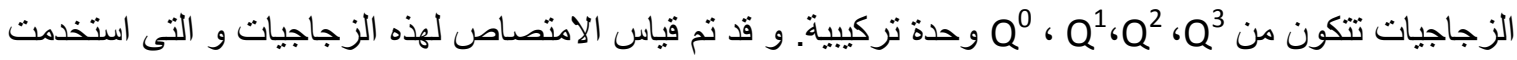

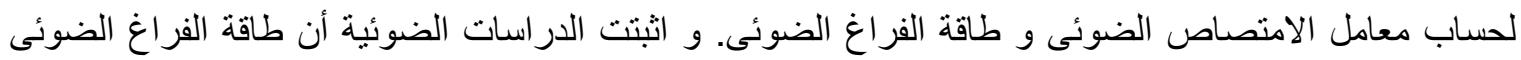

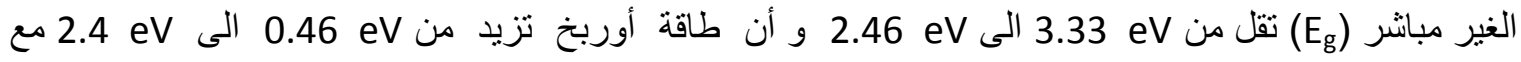

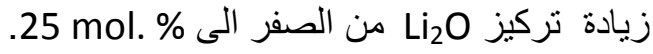

